\title{
Linking Financial Statement Valuations to the Nature of Azienda: The Theorization by Egidio Giannessi
}

\author{
Enrico Gonnella (Corresponding author) \\ Associate Professor of Financial Accounting and Business Valuation \\ University of Pisa, Pisa, Italy \\ E-mail: enrico.gonnella@unipi.it \\ Lucia Talarico \\ Assistant Professor of Financial Accounting Analysis \\ University of Pisa, Pisa, Italy \\ Received: September 25, 2018 Accepted: December 19, 2018 Published: December 27, 2018 \\ URL: https://doi.org/10.5296/ijafr.v8i4.13961
}

doi:10.5296/ijafr.v8i4.13961

The quotations of Italian writings have been translated into English by the authors of the paper.

\begin{abstract}
This paper focuses on the contribution given by Egidio Giannessi (1908-1982), the founder of the Pisa University's business school, to Italian studies in Economia Aziendale. In order to better understand his scientific profile and highlight the novelty of his thought, we have set the scholar in the scientific school of which he was one of the most prominent members, the Tuscan School of Economia Aziendale. Our study has mainly looked at two fundamental contributions of his scientific production: the general theory of azienda and the theory of financial valuation, two strictly interrelated scientific constructs where, more specifically, the latter is a consequence of the former. In the authors' opinion, it is exactly the originality of the conception of azienda formulated by Giannessi that helps understand his theory of financial valuation.
\end{abstract}

Keywords: Egidio Giannessi, General theory of azienda, Financial statement measurements, Functional value and valuation, Tuscan School of Economia Aziendale 


\section{Introduction}

Egidio Giannessi has been one of the most important Italian scholars in the field of Economia Aziendale, as well as the founder of the business school of the University of Pisa during the academic year 1955-1956. His contribution to the development of such discipline in Italy has been of paramount importance and even today his thought deeply affects research in this field and is frequently recalled in the scientific debate (see, among others: Iannone, 1993; VV.AA., 1994; Marasca, 1999, pp. 58-63; Musaio, 2005, p. 13; Tozzi et al. 2012, p. 110; Adamo, 2013, p. 591; Corsi, 2013, pp. 6-7; Paolini, 2013, p. 51; Franceschi Ferraris, 2013).

Giannessi's scientific production spans about fifty years - from the 1930's to the 1980's, i.e. from the birth of Economia Aziendale until its maturity and progressive opening to influences from the foreign scientific debate, so it expressly provides a complex and fortunate combination between innovation and continuity in the wake of tradition. The scholar owes much to his school of thought, particularly to the two decades of very close scientific cooperation with Professor Ceccherelli, the founder of the Scuola Toscana di Economia Aziendale, further developed by his direct disciples, including Giannessi himself. In spite of this, he developed a groundbreaking theory that deeply influenced the evolution of studies in Economia Aziendale in Italy.

Of the many themes dealt with by Giannessi, in this paper we will focus on the notion of azienda and the theory of financial valuation, two themes that, in our opinion, are closely interconnected in the scholar's theoretical construction, in a relationship of dependence of the latter on the former. The theory of financial valuation is inspired by the features and operating mechanisms of the azienda; this is why we cannot fully explain his ideas on financial valuation without referring to the notion of azienda he developed and to the broader scientific context within which it finds a place. For a better understanding of the factors that defined the scientific profile of the scholar, we primarily elected to recall the characteristic traits of the Italian economic and legal framework, and subsequently described the scientific reference framework, with a special focus on the most significant theoretical contributions of the Tuscan School of Economia Aziendale, where Giannessi was trained and to which he eventually contributed significantly. Following a brief biography of Giannessi is shown that highlights the location of the scholar in the context described and recalls his main publications. The purpose is to highlight the novelty of the contribution of Giannessi to the 'general theory of azienda' (Giannessi 1960, p. 85) and the theory of financial statement valuations, which will be finally analysed in depth in the last two sections of this paper.

\section{Issues for a Contextualization}

Over the period examined the Italian economy was characterised by a fast and strong development that, apart from the 1929 recession, peaked several times forming a veritable 'economic boom' after World War II (Bianco 2003). Those were the years when the Italian economic system passed progressively from being mostly agricultural and commercial to being more industrialized. The manufacturing industry increased by almost two thirds, and its workers, who did not even reach $25 \%$ of the employed population at the beginning of the century, were $45 \%$ at the end of the Sixties (Romano 1991, p. 164). The industry became the 
main activity of the Country. The economic system, which essentially consisted of small-size firms prevalently operating in the domestic market, saw the birth of the first large firms (e.g.: Edison, Fiat, Montecatini) operating in new production sectors: electricity, mechanics, automotive, and chemistry. However, the owners of the few large-size enterprises firmly and durably remained concentrated in the hands of a few families (e.g.: Agnelli, Pirelli, Orlando, Falk, Marzotto, etc.) or of the State, which, after the 1929 crisis, intervened significantly as entrepreneur in the national economy by creating the Istituto per la Ricostruzione Industriale - IRI (Institute for Industrial Reconstruction), and subsequently also with other institutions (Note 1). As a matter of fact, the separation between ownership and control, which had already taken place in other Countries (see Berle and Means, 1932), was non-existent in Italy. In the Italian context, the typical juxtaposition at governance level was not between owners and managers, but between majority shareholders and minority shareholders (Zambon and Zan, 2000, p. 804). In the SMEs as in large corporations, there was a strong concentration of ownership in the hands of a few entrepreneurs, who usually directly managed business activity. The owner was usually the only possible manager, often non-removable. The problem of the valuation of his performance was not particularly felt. It is not by chance that the theme of the choice of managers, unlike in other countries, only rarely became a crucial issue and was specifically studied by researchers (Mattessich, 2008, p. 102). The strong concentration of ownership and the low propensity to invest in stocks also explain the delayed development of the stock markets that characterised the period examined. Undeniably, in fact, after a growth phase at the start of the century (in 1907 there were 196 listed companies), starting since 1929 stock exchanges had a deep crisis that lasted even until the Eighties. In other words, the financial system was essentially 'bank-centred'. All this produced a peculiar governance model based on family-run and public-owned firms that differed from the German model, which was instead characterised by the intervention of banks even in the capitals of private enterprises, and from the Anglo-Saxon model, which was more stock market-oriented (Guatri and Vicari, 1994; Donna, 1999, pp. 43-61). Strong concentration of ownership, overlapping between ownership and control, poor development of the stock market are all useful elements to clarify the peculiar role played at that time by the financial statements in Italy: that of being a prevalently internal information tool (Viganò, 1998, pp. 394-395), with a 'private' nature, with a control function on operating trends and the duty to determine the result to be distributed, more than an external communication tool aimed at meeting public interest purposes (Poli, 1971, p. IX). Enterprises prepared an 'internal financial statement' and a 'public financial statement': the former, prepared for its own purposes, was exclusively based on accounting principles, and the latter, felt as a sort of 'legal ritual', was prepared according to civil laws and, mostly, tax laws (Viganò, 1998, p. 395). Over those years, the privileged users of financial statement were the internal parties of the azienda, owners and directors, more than external stakeholders. The Italian doctrine itself focused mainly on the internal financial statement (Viganò, 1998, p. 395).

From the point of view of accounting regulation, we should highlight, even in this case, the peculiarity of the Italian model in passing accounting and reporting rules - a typically bureaucratic model, indeed (Note 2). In Italy, as in other civil law countries, said regulations are the result of the legislative activity of the State rather than the expression of the action of 
standard setters (Di Pietra, McLeay and Riccaboni, 2001). Particularly in the period considered, the financial statement was a subject initially regulated by the Codice di Commercio of 1882, and subsequently by the Civil Code issued in 1942.

In the 1882 Code of Commerce, the subject of financial reporting was dealt with in some articles in a rather brief and incomplete manner. Referring to limited companies, said code ratified the obligation for directors to prepare the financial statement (art. 176, paragraph 1) and required it ' ... to demonstrate with evidence and truth (evidenza e verità) the actually realized profits and the suffered losses' (art. 176, paragraph 2). Furthermore, the Code established that it was forbidden to pay '... dividends to shareholders, unless on profits actually realized according to the approved financial statement' (art. 181, paragraph 1). The directors were personally liable to shareholders and third parties 'for the actual existence of the dividends paid' (art. 147, point 2). However, said indications were followed by no reference to specific valuation principles or criteria to be used to favour the achievement of the above-mentioned objectives. In this regard, the legislator had required companies only to indicate in the Articles of incorporation or in the Bylaws the standard to be complied with in '... preparing financial statements and calculating and distributing profits' (art. 89, paragraph 1, point 6). From this one can clearly infer that, although said regulations had been set forth, during the applicability period of said code $\left(1^{\text {st }}\right.$ January $1883-21^{\text {st }}$ April 1942), any valuation principle and criteria was fully lawful if compliant with the rules set forth in the Articles of incorporation or Bylaws. Hence, a wide margin of discretion remained for directors in preparing the financial statement (Ceccherelli, 1970, p. 277; Coda and Frattini, 1986, p. 113 ff.).

When the Civil Code was issued in 1942, the subject matter of financial statement valuations was defined for the first time. In particular, with art. 2425, the legislator introduced some valuation criteria concerning specific assets: tangible and intangible fixed assets, inventory, shares, fixed income securities, account receivables (Note 3). These criteria, however, seemed to be rather generic (Faccipieri and Rullani, 1982, p. 113). In addition, one should note that said valuation rules still left a wide margin of discretion to directors, reinforced by the option to make exceptions to the regulations set forth for 'special reasons' (speciali ragioni), with the only obligation for them and for statutory auditors to justify the exceptions in their respective reports (Consorti, 2001, pp. 195-196). In the period examined, in substance, accounting regulation was developed only to a limited extent. Consider that, over the period at issue, Italian professional institutions - the Collegio dei Ragionieri (CNR, Board of Accountants), created in 1910, and the Consiglio Nazionale dei Dottori Commercialisti (CNDC, National Council of Chartered Accountants), created in 1953 - had not yet taken any interest in accounting regulation. It was only in the mid-seventies that said institutions would start to develop accounting standards by creating a specific commission for the purpose (Note 4). Also note that such a situation left a wide space to the development of theories by accounting scholars.

As regards the studies in the fields of accounting and Economia Aziendale, it could be useful to mention a few significant aspects for this investigation that concern the notion of azienda and the vision of financial statement in the Italian doctrine of the time. In the period at issue, 


\section{MlMacrothink}

International Journal of Accounting and Financial Reporting

ISSN 2162-3082

2018, Vol. 8, No. 4

Gino Zappa's studies started to spread (Zappa, 1920-1929, 1927). Besta's paradigm was gradually replaced by Zappa's one (D’Amico, 1999, p. 41 ff.). By observing the ongoing changes, and particularly the increasing complexity of the manufacturing structures and operating processes of the larger firms, such as their progressive mechanization (Catturi, 1989, p. 132 ff.; Di Stefano, 1991), Zappa finally and consciously introduced in the Italian doctrine the systemic notion of the azienda (see Bertini, 1990, pp.20-28; Canziani, 2013, p. 76)), and said, about this:

'When closely observed, all the phenomena regarding the azienda ... appear established as a single coordination of economic actions aimed at achieving a specific goal. Perhaps this notion cannot be described more effectively than by using the notion of system ...' (Zappa, 1920-29, p. 330) (Note 5).

So it is not by chance that Zappa was defined as the herald of a 'radical holistic approach' (Zan, 1994, pp. 288 ff.). By adopting this perspective, the scholar gave a better interpretation of the evolution of the azienda as a phenomenon and, by so doing, he pushed accounting researchers to consider the new needs that were arising in the field of accounting. This had two significant implications: the financial position was viewed as a 'fund of coexistent values', that is '... a whole that ... determines the quantity of parts ...' (Zappa, 1920-29, pp. 15 and 3) (Note 6); the principle of the unity of operations over time, as well as in space, by virtue of which each accounting period is linked to the previous and to the next, seamlessly (Zappa, 1920-29, p. 508). This, in our opinion, favoured the development of a systemic and dynamic interpretation of the financial valuation by Italian scholars. We should also add that, over the period considered, Zappa's studies contributed in Italy to progressively replace the static vision of financial statement, typical of the $19^{\text {th }}$ century, with a dynamic notion (Alexander, Fasiello and Giaccari, 2017), in the same way as happened in Germany and in the United States (Buckmaster, 1997). The main purpose of the financial statements was no longer the determination of financial position, but the calculation of the period's income, a central theme in Zappa's vision (Canziani, 1994, p. 153; Galassi, 1996, p. 617), in order to explain, as accurately as possible, the formation of income itself. This is the aspect on which the attention of Italian accounting scholars progressively focused. So it was that, in Italy, the sistema patrimoniale (asset-based accounting), conceived by Besta, was gradually replaced by the sistema del reddito (income-based accounting) proposed by Zappa (Giannessi, 1969, p. 472).

\section{The Tuscan School of Economia Aziendale: The Main Contributions}

A 'school of thought' can be defined as a group of scholars who share a common scientific vision. But to be really defined as such, a school of thought must meet at least two requirements: the logical consistency of the key ideas developed by its members and simultaneously their capacity to be distinguished from other traditions of thought (Negru, 2013, p. 984). Usually, a school of thought is formed around a first core of innovative and original concepts developed by a person who will be later recognised as the 'founding father' of that school, to be further developed and reinforced with the contributions of the ideas of its disciples in order to investigate its subject matter more and more effectively. 
This is also the case of the School commenced in Italy by Alberto Ceccherelli (1885-1958) and further developed by his direct disciples: Alberto Riparbelli (1907-1971), Egidio Giannessi (1908-1982), and Guido Ponzanelli (1910-1984) (Note 7). Defined by Giannessi himself as one of the 'modern schools' of Italian accounting, and initially called by him Scuola Fiorentina di Ragioneria (1954, p. 409) probably referring to the origin of its leader and to the place where he conducted its activity, the University of Florence, it has long become known as Scuola Toscana di Economia Aziendale (see Bandettini et al., 1996).

As we said above, a school of thought is a system of ideas shared by a group of scholars; more specifically, these ideas may concern, inter alia, the following aspects:

- the specific subjects of research of the school itself,

- the research direction and study methodology adopted by its members, and

- $\quad$ the theoretical notions developed by them.

When reviewing the studies produced by the Tuscan School of Economia Aziendale, one aspect that is very clearly and immediately revealed by our analysis is that its members, starting with Ceccherelli, devoted to research, each according to his own inclinations, in both fields - accounting and Economia Aziendale. So, we are in front of researchers with wide-spanning interests, who deeply believed in a unitary notion of the disciplines regarding the azienda (Bertini, 2010, p. 681).

This having been said, the preferred scopes of investigation of Tuscan scholars, as far as accounting is concerned, seem to be mostly the history of accounting practices (Ceccherelli, 1910; 1913a; 1913b; 1914a; 1914b; 1914c; 1915; 1938) and accounting doctrines (Giannessi, 1954; 1964; Riparbelli. 1952); the content and the scientific orientation of accounting (Ceccherelli 1922 and 1934); economic-financial planning and, more generally, prospective investigation (Ceccherelli, 1931 and 1936a; Giannessi, 1955 and 1957; 1960, pp. 541-588); the theory of the financial statement (Ceccherelli, 1921; 1928; 1933; 1939a; 1939b; 1949; 1951; Riparbelli, 1943; Giannessi, 1960, pp. 589-742 and 794-826; 1978), with a special focus on financial valuation; production costs (Ceccherelli, 1936a and 1936b; Giannessi, 1935 and 1943; Ponzanelli, 1964); and, accounting education issues (Ceccherelli, 1958, Riparbelli, 1952; Giannessi, 1954, pp. 3-91).

As regards the Economia Aziendale, the Tuscan School devoted more specifically to the development of a general theory of the azienda (Ceccherelli, 1964, p. 18) considered as a fundamental field of investigation of Economia Aziendale itself (Ceccherelli, 1948, p. 15; 1964, p. 25) (Note 8). This was an innovative approach to these studies, one that was introduced by the Tuscan School in Italy, and particularly by Ceccherelli, who defined the content of Economia Aziendale as follows, inter alia:

'The determination of the main object of the investigation includes the development of a theory of the azienda, not as a contingent or accessory element, such as accounting and management consider it, but as the very fabric of an orderly constructive drawing.' (Ceccherelli, 1948, p. 15) 
Indeed, in those years the theme of the azienda was being tackled more as a theoretical introduction to accounting by Italian scholars (Ceccherelli, 1964, p. 18). They merely looked for a definition of the azienda and classified the different types of azienda, while developing accounting theories, to provide a stronger foundation to accounting (Ceccherelli, 1964, p. 18). With Ceccherelli and his disciples, the interest for the subject took on a totally new meaning: studying the azienda became an end in itself and a research on how the phenomenon worked, even by investigating the relationships between the azienda and its surrounding environment (Ceccherelli, 1923, 1948 and 1964; Riparbelli, 1954 and 1962; Giannessi, 1960, pp. 39-462; 1961 and 1969; Ponzanelli, 1956, 1961 and 1977). So, the azienda was sometimes observed by adopting the organic analogy, i.e. by comparing it to a living organism, which was the thesis advocated by Ceccherelli, Riparbelli and Ponzanelli; but in other cases the mechanical analogy was used, to consider the azienda as a system, as Giannessi did. The two interpretations are not in contradiction with one another, as it may seem; on the contrary, they have significant similarities. Apart from the specificities that differentiate the organic from the systemic vision, it is not difficult to note that, in the two approaches, the azienda is always seen as a whole (an organism or a system), consisting of a number of interrelated parts (organs or elements), characterised as an entity open towards the external environment, having a dynamic nature, with operating structures and processes, aimed at achieving a goal. Finally, one further feature that characterises Tuscan studies is that the azienda was looked at not only in its physiological manifestations, but also in its pathological ones (Riparbelli, 1950).

Another distinguishing feature is the direction and the methodology of research defined by the master and his disciples. Since the first works by Ceccherelli, one clearly perceives his willingness to tackle the study of accounting - although this would also be true later on for Economia Aziendale - according to a more scientific approach, in order to favour the growth of that discipline by developing scientific theories, albeit still departing from the study of reality (Ceccherelli, 1922, p. 6; see also pp. 11-12) (Note 9).

He expanded the scope of investigation of the discipline from accounting methodology to facts and phenomena of azienda. This would allow scholars to better highlight the critical-interpretive nature of accounting and attribute to it a semiotic and cognitive value (Giannessi, 1960, p. 491). Mentioning the need to develop general theories and studying the uniformities stemming from the manifestations of the azienda, rather than merely describing accounting practices, might perhaps be taken for granted today, but was not obvious at that time.

But perhaps, the feature that most of all differentiates the School examined from the other Italian schools is to be found in the specific theoretical notions developed by its members about the function of accounting, Economia Aziendale and the relationships existing between these disciplines.

In the vision of the Tuscan School, the task of accounting is mainly to investigate the phenomena of the life of the azienda (Ceccherelli, 1934, p. 122; Riparbelli, 1950, p. 11). Therefore, the function of this discipline cannot be limited to bookkeeping - a useful activity, 
indeed, to recall the transactions carried out and consequently to control the directors' behaviour - but must ' $\ldots$ reach, through observations, interpretations and deductions, an in-depth knowledge of dynamics of the azienda' (Ceccherelli, 1934, p. 122; see also: Ceccherelli, 1948, pp. 3-4; Riparbelli, 1950, pp. 9-13; Giannessi, 1954, p. 417; Ponzanelli, 1961, pp. 87-89). The recording of financial transactions is not an end in itself, but the means to achieve the true purpose of the discipline: to know and interpret an azienda's phenomena. Knowledge and study of management are essential both to produce accounting reports, such as the financial statements, and to infer operating trends from the information so produced. There is nothing mechanical in the process of 'converting an azienda's dynamics into figures' and 'reconverting figures into economic trends' (Giannessi, 1960, p. 494 and 509) (Note 10). This is a nodal point that the Tuscan authors repeatedly stress: both the activities recalled above, of which accounting studies the guiding principles (Giannessi, 1954, p. 417), require an interpretive process where humans play a determining role.

At this point, we seem to be able to say that the Tuscan scholars propose a peculiar notion of accounting, which is seen as a discipline aimed at producing information suitable to meet the needs of management; in other words, a discipline mainly focused on the decision-making process (Antonelli and Sargiacomo, 2015, p. 124). In this regard, Ceccherelli said:

'... accounting does not offer only measurement procedures, but also administrative provisions.' (Ceccherelli, 1934, p. 123).

The Tuscan School is also characterised by a peculiar notion of Economia Aziendale, other than Gino Zappa's orthodox vision (Zappa, 1927). Indeed, Economia Aziendale is not seen as the mere combination of three doctrines - accounting, management and organization - but as a higher-level theoretical system consisting of general principles, particularly of the theory of the azienda, which cannot be logically positioned among the minor doctrines above mentioned. Economia Aziendale, which 'is a special spontaneous evolution of accounting ...', according to Ceccherelli can be defined, in fact, as ' ... a synthesis of general deductions outside and beyond the individual specialisations ...' (Ceccherelli, 1948, p. 14). A particularly interesting aspect of the Tuscan approach is also the relationship existing between Economia Aziendale and Accounting. If we accept that Economia Aziendale, being focused on '.. the real life of firms, considered in the transformation processes that, through the concrete phenomena of the operation and investment of capitals, of the costs and of the revenues lead to the product and profit' (Ceccherelli, 1948, p. 33), then it is evident that the theories developed by this discipline '... always find their origin and their cause in a process of economic-technical interpretation of numerical values, processed and collected according to the rules of the accounting methodology' (Ceccherelli, 1948, pp. 14-15) (Note 11). In such a theoretical system, accounting offers Economia Aziendale some 'food for thought' by providing it with its natural 'raw material'. On the other hand, since it deals with the general principles that concern the operation of the azienda, we may define Economia Aziendale as '... a science ... that provides a general introduction to the knowledge of the firm universe' (Giannessi, 1960, pp. 21-22). For this reason, it seems we can say that Economia Aziendale, and particularly the theory of the azienda, provides a valuable framework within which we can build the interpretive processes implemented by accounting (Ceccherelli, 1931, p. 6; 
Riparbelli,1968, p. 14) (Note 12).

\section{Egidio Giannessi: A Short Biography}

Egidio Giannessi was born in Pisa on 28 July 1908. In 1932 he graduated magna cum laude in Tecnica Industriale (Management) working with Prof. Teodoro D'Ippolito at the Regio Istituto Superiore di Scienze Economiche e Commerciali of Florence. His scientific education was undoubtedly very positively affected by contacts with other academic milieus outside the Florentine university. One particularly fruitful intellectual exchange was his collaboration with the Bocconi University in Milan, where he worked as volunteer assistant of D'Ippolito (Giannessi, 1971, p. 3) and where he could meet Gino Zappa, the founder of the Italian Economia Aziendale.

The year 1936 was very important in Giannessi's life, as he left Milan and went back to Tuscany to teach in a secondary school (Note 13). At that time he met Prof. Ceccherelli at the University of Florence, who offered Giannessi to become his assistant (Giannessi, 1971, p. 4). So, he worked as Adjunct Assistant Professor in the Chair of Accounting and Calculations, teaching courses in Management of Industrial Firms and Management of Farms and Mining Firms at the University of Florence from the 30's to the 50's (Miolo Vitali and Gonnella, 2006, p. 577). Over that period Giannessi continued as Adjunct Assistant Professor in Florence and also worked in Pisa, where he had obtained the Chair of Accounting at the Istituto Tecnico Commerciale (Business Secondary School). In 1956, Giannessi won the public competition organised by the University of Parma. After one year in Parma, in 1957, he moved to the University of Pisa, where he had already been teaching since the academic year 1955-1956 as Lecturer, when the Faculty of Economics and Trade was opened. Since 1957, he held the Chair of General and Applied Accounting in Pisa, where he became full professor. He kept this chair until May 1978, when he retired. He died in Pisa on 13 July 1982.

The table below lists the most important among his numerous publications, prevalently in Italian, but also in German, English and Portuguese, in chronological order (Note 14).

Table 1. Main publications of Egidio Giannessi

\begin{tabular}{lllllll}
\hline Year & Original title & & English translation \\
\hline 1935 & $\begin{array}{l}\text { I costi di produzione nelle imprese } \\
\text { cotoniere }\end{array}$ & Production Costs of Cotton Firms \\
\hline 1943 & $\begin{array}{l}\text { Costi e prezzi-tipo nelle } \\
\text { industriali }\end{array}$ & aziende & $\begin{array}{l}\text { Standard Costs and Prices of } \\
\text { Industrial Firms }\end{array}$ & \\
\hline 1954 & $\begin{array}{l}\text { Attuali tendenze delle dottrine } \\
\text { economico-tecniche italiane }\end{array}$ & $\begin{array}{l}\text { Current Trends of Italian Economic } \\
\text { and Technical Doctrines }\end{array}$ \\
\hline
\end{tabular}


1955 L'equazione del fabbisogno di

produzione e le possibili vie della sua soluzione

The Equation of Financing Needs of Firms and Possible Ways of Its Solution

1957

Il piano finanziario nel sistema dei The Financial Plan within the System piani d'azienda of Business Plans

1958 Il Kreislauf tra costi e prezzi come elemento determinante delle

1982 condizioni di equilibrio del sistema d'azienda

The 'Circularity' between Costs and Prices as Driver of Firm's Equilibrium

Le aziende di produzione originaria, The Primary Activities Firms, Vol. I, Vol. I, Le aziende agricole The Farms

1964

1971

1974

I precursori in Economia Aziendale

1980

Considerazioni critiche intorno al Critical Considerations on the concetto di azienda

The Forerunners of Economia Aziendale

1978 Osservazioni intorno al significato dei bilanci
Concept of Azienda
Observations about the significance of financial statements

1992

$\begin{array}{lccc}\begin{array}{l}\text { Considerazioni } \\ \text { metodo storico }\end{array} & \text { introduttive sul Introductory Considerations to } \\ \text { Historical Method }\end{array}$

Source: Our elaboration

Giannessi also had a long cooperation with several Italian scientific reviews, such as the Rivista Italiana di Ragioneria, and also foreign scientific journals, such as Der Österreichische Betriebswirt, Zeitschrift für handelswissenschaftliche Forschung, Zeitschrift für Betriebswirtschaft, in German, and the Revista Paulista de Contabilidade, in Portuguese (Corticelli, 1982, pp. 489-490).

The listed publications provide evidence of the multiple themes dealt with by the scholar and the broad range of his scientific interests, as well as the novelty and interdisciplinary nature of his approach, which certainly also benefited from the juvenile experience in the Milan universities and in Zappa's school. 
Continuity with the thought of his master Ceccherelli did not prevent Giannessi from starting an important theoretical change for the Tuscan School with groundbreaking contributions on a range of subjects, some of which are recalled below:

- General theory of the azienda;

- Financial statements and financial valuations;

- Production costs;

- Financial issues of firms;

- Accounting history;

- $\quad$ Research methodologies.

This paper will focus on two of the most significant subjects in Giannessi's scientific production: the general theory of the azienda and financial valuation.

\section{The General Theory of the Azienda}

One of the main contributions fed by Giannessi to studies in Economia Aziendale is his personal general theory of the azienda. Before examining this theory, however, it is right to specify the meaning of the term azienda within the framework of Economia Aziendale (Viganò and Mattessich, 2007, pp. 25-26). In Italian studies, the term azienda is used with reference to different kinds of human organisations created and managed with the purpose of conducting an economic activity aimed to produce or consume/distribute wealth. Within such a framework, the notion of azienda includes both 'public organisations' and 'private organisations', namely public administrations like the State itself and its local governmental units, in the former group, and profit organizations or firms (also called businesses or enterprises) and not-for-profit organizations, such as foundations and associations (e.g. NGOs and other not-for-profit organizations) and households, in the latter group. More specifically, it should be pointed out that, in Italian studies, the enterprise is a special form of azienda whose prevalent function is the production of new wealth.

After this necessary premise, we may recall Giannessi's words, which describe the azienda as:

'... a system of operations, that derives from the combination of specific [productive] factors and from the composition of internal and external forces, where the phenomena of production, distribution and consumption are arranged for the purpose of achieving a given economic equilibrium, that has to be valid over time, susceptible of offering an adequate remuneration to the factors used and a reward, proportional to the results achieved, to the economic actor on behalf of which the activity is carried out.' (Giannessi, 1960, p. 46) (Note 15).

Giannessi particularly highlighted three elements, which were later defined as the three constituents of the azienda (Gonnella, 2014): the operations ('system of operations'), the productive structure ('combination of specific factors'), and the relationship between the azienda and the environment ('composition of internal and external forces'). 
According to the scholar, the various manifestations of the economic activity substantiate in the azienda: the production of goods and services, their distribution and their consumption for the satisfaction of human needs.

The aspect that should be particularly highlighted, also for its connection with the theory of financial valuation conceived by the scholar, is that the survival and development of the azienda are linked with the achievement of a given long-run economic equilibrium. The economic equilibrium is nothing but a cost/revenue relationship. In the long period, revenues have to be appropriate for covering costs and for leaving an adequate margin for the 'economic actor', namely the individual or the group on behalf of whom the activity is carried out. The need to achieve this economic equilibrium over a long period of time is, in Giannessi's general theory of the azienda, exactly the common denominator of each form of azienda.

As regards the achievement of the economic equilibrium as a basis for the azienda, Giannessi further specified:

'The economic equilibrium of the azienda may be considered as established only when the following conditions are met:

- The results must be such as to permit an adequate remuneration of all factors, none excluded, which took part in the combination of the azienda;

- The results must permit the awarding of a return, determined proportionally to said results, for the 'economic actor' on behalf of whom the activity is carried out. Said return may be reduced down to a minimum, but it may not be lacking; over time, it has to balance itself on an average return that is remunerative for the investment or remain above the such average return;

- Both the adequate remuneration of the factors that took part in the productive combination and the return due to the 'economic actor' must be ensured for a period of time that must be considered satisfactory in probabilistic terms.' (Giannessi, 1960, pp. 74-75).

The excerpt above shows quite clearly that the elements at the basis of the achievement of the economic equilibrium are both the measure of the rewards paid to the various productive factors and to the 'economic actor', and the their duration: the measure must be adequate and the duration must be ensured for a satisfactory period of time (Giannessi, 1960, p. 93).

At this point, we should better clarify the notion of remuneration of productive factors, before examining its adequacy. There are two kinds of remunerations: sometimes they are prices negotiated within the framework of exchange transactions with third parties, as in the case of productive factors like raw materials, human labour, services; other times, they are the result of valuations made by the azienda, such as in the case of the depreciation and amortization of assets and the provisions for risks and charges. The two types of remuneration are defined by Giannessi as 'external' and 'internal' rewards, respectively (Giannessi, 1960, p. 75). Therefore, it appears clear why Giannessi observed the following concerning the adequacy of the remuneration of the various productive factors: 


\section{MInstitute Mach $^{\text {In }}$}

International Journal of Accounting and Financial Reporting

ISSN 2162-3082

'The remuneration that is due to the productive factors must be adequate. This condition may be considered as met when the remuneration does not differ much from market price levels, for external rewards, and from the functional valuation criteria adopted by the azienda in the formulation of its period assumptions, for internal rewards.' (Giannessi, 1960, p. 75).

The meaning of the expression 'functional valuation' is provided in the next section. Note that it is precisely financial valuations that determine the internal remunerations, thus affecting the equilibrium positions of the azienda and the return that can be paid to the 'economic actor'. In fact, in this regard, Giannessi maintained:

'The determination of the adequate remuneration of productive factors is a particularly difficult aspect of the valuation problem in azienda.' (Giannessi, 1960, p. 75).

The scholar classified the possible situations regarding the dynamics of the azienda based on the level of return and its trend. As regards the first parameter, he defined three different areas: equilibrium, disequilibrium and uncertainty. As to the second parameter, he identified two possible situations: the evolutive trend and involutive trend of economic equilibrium. By combining these two parameters, Giannessi eventually produced the following interpretative scheme of the dynamics of the azienda.

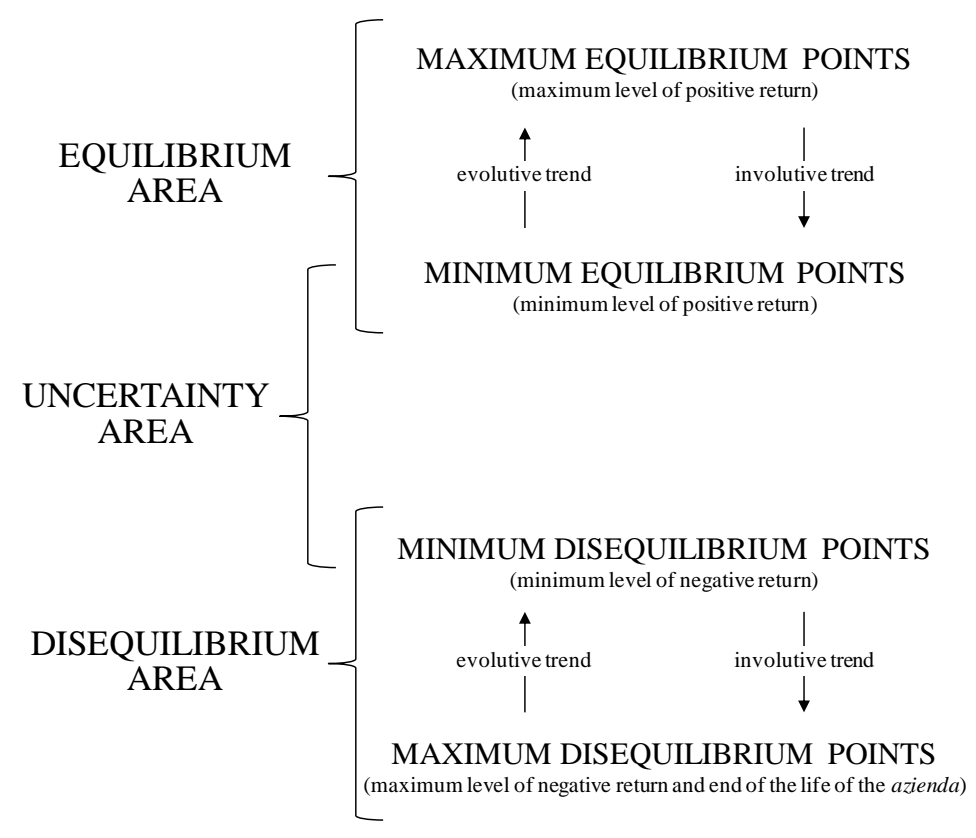

Figure 1 . The dynamics of the azienda

Source: Giannessi, 1960, p. 94

In Giannessi's vision, the continuous reference to the equilibrium positions reached by the azienda is essential both for decision-making (Giannessi, 1960, p. 93) and for financial valuation (Giannessi, 1960, p. 591).

\section{From the Equilibrium of Azienda to the Theory of 'Functional Value'}

In Giannessi's thought, the theory of financial valuation is closely related to the theory of azienda. To justify this consideration, we should recall the notion of accounting developed by 
Giannessi. He conceived accounting as a 'science that studies the conversion of azienda's dynamics into numbers and the reconversion of these numbers into economic trends' (Giannessi, 1960, p. 22). In such a context, the financial statement is viewed as a historical-probabilistic document (Giannessi, 1960, p. 815), with the purpose of ' $\ldots$ determining an appropriate result to identify the positions of equilibrium of the azienda and the nature of their related motion' (Giannessi, 1960, p. 805).

Regarding the historical-probabilistic nature of financial statement, Giannessi stated:

'The financial statement ... is historical because it contains data regarding the past of which it can offer an effective synthesis, and it is probabilistic because it contains data on the valuation of equipment, inventories and risks by which it somehow anticipates future operations' (Giannessi, 1969, p. 799).

This is the reason that pushes Giannessi to define the results of the financial statement as probabilistic, because they depend on how much the underlying assumptions of the financial statement's valuations reflect reality.

However, we should clarify that income is in any case insufficient to represent the positions of equilibrium of the azienda; while the former has a contingent and speculative nature (Giannessi, 1960, p. 69), the latter may only be conceived, according to Giannessi, in a necessarily broader temporal perspective than the accounting period. In fact, Giannessi wrote:

'The period's income is not appropriate to represent the equilibrium of the azienda; it may be one of the elements for judgement, but not the only and absolute element for judgement.' (Giannessi, 1960, p. 74).

The motion of the azienda has a variable character and it never takes a 'definitive position', so the consequent equilibrium '... tends to continuously decompose and recompose ...' (Giannessi 1960, p. 93).

The period's income, being a point value, may only be used to capture an image of the motion of the azienda, but it will never suffice alone to reproduce the dynamics of the azienda. It is a necessary tile of a wider mosaic. Only a range of incomes observed in their evolution over time can be of help in recovering a diachronic perspective, and therefore in conceiving an idea of the motion of the azienda.

Giannessi himself highlighted this when he wrote:

'For a sufficiently accurate idea of the motion of the azienda, we have to carry out a series of repeated measurements and compare the results obtained among each others.' (Giannessi, 1960, p. 93).

In such a theoretical context, financial valuations take up a central role in the reconstruction of the dynamics of the azienda and give an important contribution to the comprehension of the conditions of equilibrium of the azienda itself.

In general, 'to valuate - Giannessi wrote - means to express the essence of an asset in monetary terms' (Giannessi, 1960, p. 589). There are different types of valuations in azienda: 
financial statement valuations, liquidation valuations, and the valuation performed when buying or selling a business. Of these three, Giannessi mainly focused on financial statement valuations, namely '.. the most significant expression of the valuation process' (Giannessi, 1960, p. 598). This is explained by the particular recurrence and function of valuation, which depend on the recurrence and function of the financial statement. If, for Giannessi, the financial statement is a '... tool through which a given dynamic position of the life of the azienda is represented' (Giannessi, 1960, p. 799), the financial statement valuation may have the only purpose of '.. determining the degree of functionality of the azienda' (Giannessi, 1960, p. 590).

To achieve the objective, it must be managed according to a specific process and by adopting a given perspective, which Giannessi summarised in the expression 'functional valuation' since this valuation '... implies the determination of the notion of functionality', that it to say of the '... position of each factor within the economic combination of the azienda' (Giannessi, 1960, pp. 738-739). In other terms, the valuation cannot be simply resolved in the mere assessment of asset per se, but it also requires considering the way in which the factor becomes a part of the productive combination.

The valuation process consists in a number of steps and generates the 'functional value' by successive approximations. The first step consists in the identification of the nature of the asset to be valued, which gives a first attribution of value; however, that initial value must be re-determined. In fact, when the asset becomes part of the productive combination, it ceases to be a free asset and becomes a productive factor, i.e. part of the system of the azienda. Ignoring this change in the valuation of the asset would be denying the very systemic nature of the azienda (Giannessi, 1960, pp. 697-698). This is a central point in Giannessi's thought, one that seems to find its logical assumption in the research on the different possible combinations of productive factors initiated by Ceccherelli and later continued and studied more in depth by Giannessi. According to Giannessi, in fact, productive factors individually considered are not useful for the azienda (Note 16). Their utility only emerges if we observe them properly combined with each other, as they are effectively in the azienda system (Note 17). In other words, Giannessi believed that valuation should not neglect an important feature of the productive structure of the azienda, i.e. the complementarity of its productive factors. One may also say that Giannessi transposed this property - complementarity - from the economy of the azienda to accounting, from the theory of the azienda to the theory of financial valuations. Productive factors should not be valued individually, as if they were independent entities and by observing only their intrinsic features, but rather as parts of a whole. The valuation of each individual item of the capital is affected by how each given element is combined with the others (n-1) and by the relationships between them. Hence, the same productive factor will have a different value in different aziende (Note 18). Identical assets available in the market traded at identical prices will have different functional values when cease to be 'free' and become the productive factors of different aziende (Giannessi, 1960, p. 698).

The contribution of the productive factor to the system also changes with the condition and direction of the equilibrium/disequilibrium of the azienda. The azienda - we should repeat - 
is not a temporary but a medium/long term phenomenon. So, it cannot be understood and analysed outside its temporal perspective. This means that, whenever the azienda finds itself in conditions of evolutionary equilibrium, the degree of utilisation of productive factors will likely increase over time in consideration of the positive perspectives; therefore, their value shall be increased. Vice versa, if the azienda, although in equilibrium, follows a decreasing path, the economic contribution of the productive factors will likely decrease in consideration of the negative perspectives; hence their value should be reduced.

The functional value has a special feature: unlike other types of values (e.g. historical cost, current cash equivalent, etc.) it does not immediately refer to a real or assumed economic transaction, but stems from a firm-specific valuation (Note 19). It is a value-in-use estimated as a function of the usefulness of the productive factor for the considered azienda. This does not mean that Giannessi ignored the utility of the historical cost, the replacement cost, the net realizable value or other values taken from the market, but it means that they are not identified as functional value, but rather as simple elements required for a judgement on the formulation of the functional value. What is missing, in the end, is a direct link between value and economic transaction, which is typical of other valuation theories (see Lee 1998: p. 26), precisely because the functional value is peculiar to each azienda and to the conditions of its dynamics.

The complexity of the valuation process is also increased by its necessary iterative nature. In fact, the functional value is obtained by successive approximations, by repeating the valuation process many times until the most appropriate value is identified. The preparers of financial statements have to carefully examine the effects that are produced, from time to time, during successive steps, on two fronts: that of the period income and that of the economic equilibrium, until a satisfying solution is reached. Iterativity depends on the circularity that is established among the estimate of the productive factors, their (internal) remuneration, and the equilibrium of the azienda. We have already noticed how the equilibrium exists, for the scholar, only if the azienda is capable of adequately remunerating the productive factors used and of adequately rewarding the 'economic actor'. The remuneration of factors and the reward for the 'economic actor', in their turn, cannot be determined but by taking into account the equilibrium positions of the azienda. Giannessi saw the problem clearly, as he stated:

'Equilibrium positions cannot be identified before determining the remuneration of productive factors and the reward for the economic actor; the remuneration of factors and the reward for the economic actor cannot be determined before ensuring the survival of the equilibrium positions over time' (Giannessi, 1960, p. 591).

It is, therefore, only through a iterative process that directors may reach appropriate financial valuations capable of determining an '... income for the period to be used in the reconstruction of the equilibrium positions of the system of the azienda and in the identification of the characteristics of its motion' (Giannessi, 1960, p. 824).

Let's see, for instance, what Giannessi suggests for the valuation both of the equipment and machinery, and of the products of the farms. 


\section{Ml Macrothink}

International Journal of Accounting and Financial Reporting

ISSN 2162-3082

2018, Vol. 8, No. 4

In order to determine the functional value of equipment and machinery, one should primarily obtain accounting data like the 'historical cost', 'extraordinary maintenance and repair costs' and the 'reproduction cost' (Giannessi, 1960, p. 678-679). However, these data are not sufficient. In this regard, Giannessi says:

'The historical cost, extraordinary maintenance and repair costs and the reproduction cost are all useful elements to be used for judgement, but do not consist in the judgement itself. In order to express the latter and formulate the functional valuation of the machine, one must adjust the data so obtained to the specific situation of the firm and the market to which the calculation refers' (Giannessi, 1960, p. 681).

In Giannessi's theoretical system the valuation of equipment and machinery, as for any other asset, requires the formulation of a veritable judgement, which must rest on adequate pieces of information. This is the reason why the scholar accurately indicates a set of informative elements to be examined for valuation of equipment and machinery (Giannessi, 1960, p. 679; see also pp. 820-821):

- $\quad$ The positions of equilibrium of the firm;

- $\quad$ The trend (evolutive or involutive) of equilibrium of the firm;

- $\quad$ The production and sales volumes;

- The technical situation of firm;

- $\quad$ The economic situation of firm;

- The financial situation of firm;

- Any other element capable of distinguishing a given productive combination from another;

- The general and particular conditions of the economy;

- $\quad$ The price fluctuations, and;

- The inflation.

These elements must be examined in addition to the historical cost, to the extraordinary maintenance and repair costs and to the reproduction cost, in order to formulate the evaluation of the equipment and machinery.

The approach that consists in examining the various elements for judgement to be considered in financial statement valuation is also found in the functional valuation of agricultural products. When he discusses the functional valuation of the products of farms, Giannessi identifies three first elements for judgement (Giannessi, 1960, pp. 711-714):

- The destination of products;

- The state of negotiations;

- $\quad$ The degree of preservability of products . 
In Giannessi's view, in fact, the value of agricultural products changes if they are destined to the reuse in production or to the sale in the market, according to the presence or absence of sales agreements of various kinds or commitments to sign agreements and to the possibility of preservation of the products for a longer or shorter period of time after harvest. The value of products must take into account the various possible situations that concern said parameters. But that is not all. Giannessi writes:

'The functional valuation [of the agricultural products] implies the consideration of all the technical, economic and financial conditions that identify product batches. Technical conditions are important for the relationship existing between products to be reused in production and products to be directly sold in the market; the economic conditions for the relationship existing between historical pricing and the probabilistic determination of prices; the financial conditions for the interest the firm may have to sell immediately, or wait for the most appropriate time ...' (Giannessi, 1960, p. 714; see also pp. 821-822).

We can say, ultimately, that for Giannessi valuation is a logical operation that transcends any rigid and mechanical application of valuation criteria (Note 20). Vice versa, it consists in formulating a judgement starting from an adequate system of quantitative and qualitative information elements, concerning essential aspects of the firm and its surrounding environment (Note 21). These elements for judgement must be identified on a case by case basis, in connection with the asset to be estimated; this is the reason why they change between assets. The judgement so formed is a summary of the different pieces of information available, although it differs from each one of them. In this regard Giannessi says:

'The functional criterion uses all the data available, both historical and related to the market, but does not coincide with any of them' (Giannessi, 1960, p. 709).

So, what is the role played by valuation criteria in the theory of valuation at issue? We may answer that they lose their status of valuation rules and take on the role of elements for judgement, together with other kinds of information to be used for valuation. This is a leitmotiv of Giannessi's thought (Note 22).

In summary, the functional valuation consists in a highly discretionary judgement based on a complex system of quantitative/qualitative information (Note 23), which concern certain essential features of the azienda and its environment. Such an approach, on the one hand, threatens the very function of the financial statement as an instrument for the control of the actions carried out by directors and, on the other hand, enhances the efficacy of the financial statement for the purpose of exercising an internal control on corporate trends. This is precisely the perspective adopted by Giannessi, and shared by most Italian scholars of the time (Note 24). The information we can infer from the financial statements prepared with functional values is particularly useful to help managers make decisions, also regarding strategic problems. This is the reason why said values are consistent with the notion of the financial statements as a tool for the control of the economic trends of enterprise. This is in line with the characteristics of the Italian economic system of the time, which mainly consisted in small-size firms, sole or one-family proprietorship, and only in rare cases in large family-run or State-owned enterprises, but which did not yet include cases of significant 
separation between ownership and control, and where the stock market was hardly making its way ahead. Only when these conditions started changing, from the beginning of the seventies, Italian accounting would be pushed to redesign the financial statement as a tool for communication with the external world, in order to meet public interest purposes (Poli, 1971, p. 113 and ff) (Note 25).

\section{Concluding Remarks}

In the paper we dealt with two of the most significant themes of Giannessi's thought - the notion of azienda and 'functional valuation' - which, being closely interrelated, show all the intrinsic coherence of the thought of the scholar.

The systemic vision of the azienda is closely related with the theme of financial valuations, which flowed into the theory of functional value.

The functional value, developed by Giannessi, aims to express, in terms of values, the economic attitude of the different production factors that take part in the combination of the azienda, that is to say the contribution given to the achievement of the degree of functionality of the azienda. This value is, therefore, reached - as we have seen - only at the end of a complex and multifaceted logical process which starts with the assessment of the value of the individual asset, but then requires subsequent repeated revisions aimed at detecting the links of complementarity among the different assets, also in the light of the evolutive or involutive conditions and of the dynamics of the azienda (Note 26).

The functional value derives its qualifying features from the properties of the azienda as a phenomenon; in fact, it has a systematic, dynamic, and probabilistic nature (Giannessi, 1956, p. 103).

Its systematic nature stems from the fact that the functional value of an asset must express its productive possibilities within a given productive combination. The value must fully reflect the complementary nature of productive factors. Actually, the theme of the conjunction of productive factors was not new in the Italian doctrine on this subject matter, as other Italian scholars had already mentioned it in their works (Note 27), but it was only with the functional valuation that the link between the complementarity of productive factors and going-concern values became a qualifying element. This is why we can share the opinion expressed in the literature, according to which the functional value, unlike other valuation bases, has an intrinsically relational character (Note 28).

The functional valuation also reflects the dynamic nature of the azienda; the value judgement, in fact, is drawn from historical, contingent and future data, by following a diachronic approach.

Finally, the functional valuation has a probabilistic nature, as the financial statement values are influenced by the perspectives on future trends of the azienda and of the reference environment.

Based on the consideration developed, we believe we could say that functional valuation is the clearest expression of the holistic approach to the valuation problem, typical of the Italian 
tradition, which contrasts the extreme simplification of a valuation process that is reduced to the adoption of standardized criteria. The functional valuation reflects the complexity of the azienda in the financial statement, which is transformed from an aggregation of values to an actual 'system of values' (Onida, 1940, p. 74).

However, we cannot deny that the functional valuation is based - as we repeatedly highlighted - on a judgement formed by the preparers of the financial statement. Such judgement is characterised by a high level of subjectivity and uncertainty. So, the discretionary nature that is typical of every valuation is even reinforced in this case, because the valuation is guided by a principle and is no longer bound to a criterion; this allows a greater degree of freedom to the preparers of the financial statement. Moreover, the complexity of the process that leads to the final value, which examines many valuation parameters, increases its intrinsic subjectivity and uncertainty. Being an entity-specific valuation, which also reflects the expectations, the assumptions and the intentions of directors, functional valuation is strongly affected by the 'personal equation' of the preparer of the financial statement (Note 29), and consequently it can be more easily manipulated. And, for the same reason, it is more difficult to audit.

But another limit also emerges clearly: the functional valuation process a rather difficult one to implement and very time and energy consuming. In fact, the formation of a judgement requires a preliminary collection and careful analysis of a large information base, including both quantitative and qualitative information, and the research, finally, of a point of convergence capable of providing a solution for the problem of the circular relationship existing between the period's income and the perspective economic equilibrium.

We may conclude that the main strength of the theory of functional valuation is its foremost weakness too. In other words, functional valuation draws its inspiration from a robust theory of the azienda and an approach that considers the financial statement as a tool to be used to understand the equilibrium conditions of a specific azienda for prevalent internal control purposes. Hence the need for financial valuations to reflect the conditions of the dynamics of the azienda, and therefore share with it the features of complexity and uniqueness. Subjectivity and application challenges are the consequences.

In spite of the limits described, we believe that the contribution of the theory formulated by Giannessi to the doctrinal growth of the Italian accounting is undeniable, although such theoretical construct did not directly lead to changes in accounting regulation and practices (see Alexander and Servalli 2011) (Note 30). The valuation approach adopted stands out for its broad theoretical foundation, which aims at defining a guiding principle rather than at prescribing standardized technical rules and regulations. The result is a veritable theory of value in a Schumpeterian sense (Note 31), one closely related to the azienda-phenomenon. The novelty of the approach is also proved by the fact that the functional value is characterised as a usage value, unlike the most common approaches that connect financial statement values either directly or indirectly to market transactions (Note 32). It is probably due to this doctrinal robustness that the theory of the functional value still continues to arouse a scientific interest in Italy. 


\section{References}

Adamo, S. (2013). Le rivelazioni di esercizio delle imprese. Scritture complesse e sintesi periodiche. Bari: Cacucci.

Alexander, D., \& Servalli, S. (2011). Economia aziendale and financial valuations in Italy: Some contradictions and insights. Accounting History, 16, 291-312.

Alexander, D., Fasiello, R., \& Giaccari, F. (2017). Income measurement and asset valuation under Zappa' s theory. In Alexander, D. et al. (Eds.), The History and Tradition of Accounting in Italy. London: Routledge.

Alfieri, V. (1923). Le rilevazioni amministrative. Rivista Italiana di Ragioneria, 23.

Antonelli, V., \& Sargiacomo, M. (2015). Alberto Ceccherelli (1885-1958): Pioneer in the History of Accounting Practice and Leader in International Dissemination. Accounting History Review, 25, 121-44.

Antoni, T. (1979). Ricordo di Gino Zappa e di Alberto Ceccherelli. Rivista Italiana di Ragioneria e di Economia Aziendale, 79.

Bandettini, A., Catturi, G., Franceschi Ferraris, R., \& Pezzoli, S. (1996). La scuola toscana di Economia Aziendale: Alberto Ceccherelli ed $i$ suoi primi allievi. Padova: Cedam.

Barth, M. E. (2006). Including Estimates of the Future in Today's Financial Statements. Accounting Horizons, 20, 271-285.

Barth, M. E. (2010). Comments on panelists. Abacus, 46, 120-127.

Bergamin Barbato, M., Collini, P., \& Quagli, A. (1996). Management accounting in Italy: evolution within tradition. In A. Bhimani (Ed.), Management Accounting: European Perspectives. New York: Oxford University Press.

Berle, A. A., \& Means, C. G. (1932). The Modern Corporation and Private Property. New York: MacMillan.

Bertini, U. (1990). Scritti di politica aziendale. Torino: Giappichelli.

Bertini, U. (2010). La scuola toscana di ragioneria e di economia aziendale. Rivista Italiana di Ragioneria e di Economia Aziendale, 110, 675-693.

Besta, F. (1909). La Ragioneria, Parte prima. Ragioneria generale, II. Milano: Vallardi.

Bianco, M. (2003). L'industria italiana. Bologna: Il Mulino.

Buckmaster, D., \& Jones, S. (1997). From balance sheet to income statement: A study of a transition in accounting thought in the USA, 1926-1936. Accounting Auditing \& Accountability Journal ,10, 198-211.

Canziani, A. (1994). Gino Zappa (1879-1960): Accounting Revolutionary. In J. R. Edwards (Ed.), Twentieth-century accounting thinkers. London: Routledge. 


\section{$\triangle$ Macrothink}

International Journal of Accounting and Financial Reporting

ISSN 2162-3082

2018, Vol. 8, No. 4

Canziani, A. (2013). Accounting and "Economia Aziendale" in Italy, 1911 Afterward. In Y. Biondi, \& S. Zambon (Eds.), Accounting and Business Economics. Insights from National Traditions. London: Routledge.

Capaldo, P. (2010). L'economia aziendale oggi. Milano: Giuffrè.

Catturi, G. (1989). Teorie contabili e scenari economico aziendali. Padova: Cedam.

Ceccherelli, A. (1910). Le scritture commerciali nelle antiche aziende fiorentine. Firenze: Lastrucci.

Ceccherelli, A. (1913a). I libri di mercatura della Banca Medici e l'applicazione della partita doppia a Firenze nel secolo decimoquarto. Firenze: Bemporad.

Ceccherelli, A. (1913b). Un libro di conti tenuto da B. Cellini al Duca Cosimo Medici. Rivista Emiliana di Ragioneria, 5, 21-30.

Ceccherelli, A. (1914a). Le funzioni contabili e giuridiche del bilancio delle società medievali. Rivista Italiana di Ragioneria, 14, 371-78.

Ceccherelli, A. (1914b). Le funzioni contabili e giuridiche del bilancio delle società medievali (Continuazione). Rivista Italiana di Ragioneria, 14, 391-95.

Ceccherelli, A. (1914c). Le funzioni contabili e giuridiche del bilancio delle società medievali (Continuazione e fine). Rivista Italiana di Ragioneria, 14, 436-45.

Ceccherelli, A. (1915). La logismologia. Milano: Vallardi.

Ceccherelli, A. (1921). La tecnica del bilancio con speciale riguardo alle aziende bancarie. Milano: Vallardi.

Ceccherelli, A. (1922). L'indirizzo teorico negli studi di ragioneria: prime linee di una introduzione allo studio della ragioneria generale. Firenze: Ariani.

Ceccherelli, A. (1923). Introduzione allo studio della ragioneria generale. Gli organismi aziendali, Firenze: Le Monnier.

Ceccherelli, A. (1928). Note sulle valutazioni contabili e sulla formazione dei bilanci commerciali. Firenze: Tipografia dei Sordomuti.

Ceccherelli, A. (1931). Le prospettive economiche e finanziarie nelle aziende commerciali, Vol. I, Gli elementi statistico contabili dell'indagine prospettiva. Firenze: Le Monnier.

Ceccherelli, A. (1933). Formazione e interpretazione dei bilanci straordinari in alcuni casi previsti dal Codice di Commercio. Milano: Giuffrè.

Ceccherelli, A. (1934). La ragioneria nel sistema delle discipline economiche e commerciali. Discorso inaugurale dell'anno accademico 1933-34 presso il Regio Istituto Superiore di Scienze Economiche e Commerciali di Firenze. Firenze: Ricci.

Ceccherelli, A. (1936a). Il problema dei costi nelle prospettive economiche e finanziarie delle imprese. Firenze: Seeber. 


\section{$\triangle$ Macrothink}

International Journal of Accounting and Financial Reporting ISSN 2162-3082

Ceccherelli, A. (1936b). Le rilevazione dei costi in relazione al fenomeno dei cicli economici. Firenze: Carlo Cya.

Ceccherelli, A. (1938). Intorno ad alcuni antichi libri di conti. Rivista Italiana di Ragioneria, 38, 81-3.

Ceccherelli, A. (1939a). Il linguaggio dei bilanci. Formazione e interpretazione dei bilanci commerciali. Firenze: Le Monnier.

Ceccherelli, A. (1939b). Valutazioni di bilancio. Rivista Italiana di Scienze Commerciali, 3, $36-45$.

Ceccherelli, A. (1948). Economia Aziendale e amministrazione delle imprese. Firenze: Barbera.

Ceccherelli, A. (1949). Valutazioni di bilancio e disposizioni di legge. Roma: Castaldi.

Ceccherelli, A. (1951). El lenguaje del balance. Traducción de la cuarta edición italiana. Madrid: Instituto de Censores Jurados de Cuentas de España.

Ceccherelli, A. (1958). La posizione attuale della ragioneria negli studi e nell'insegnamento. Convegno di studi sulla Ragioneria e Tecnica commerciale.

Ceccherelli, A. (1964). Problemi di Economia Aziendale. Pisa: Cursi.

Coda, V., \& Frattini, G. (1986). Valutazione di bilancio. Principi economici, norme civili, norme fiscali. Milano: Libreria Universitaria Editrice.

Consorti, A. (2001). L'evoluzione della funzione informativa del bilancio d'esercizio: dal conto del patrimonio al sistema delle informazioni. Torino: Giappichelli.

Corsi, K. (2013). La comunicazione dell'impairment test dell'avviamento. Tra riflessioni teoriche ed evidenze empiriche. Torino: Giappichelli.

Corticelli, R. (1981). Carattere specifico della valutazione di bilancio e accoglimento generale di principi contabili: considerazioni. In Bilancio di esercizio e amministrazione delle imprese. Studi in onore di Pietro Onida. Milano: Giuffrè.

Corticelli, R. (1982). Egidio Giannessi: il suo generoso impegno per l'Università. Rivista Italiana di Ragionetria e di Economia Aziendale, 83, 488-493.

D'Amico, L. (1999). Profili del processo evolutivo negli studi di economia aziendale. Schemi di analisi per 'paradigmi' e 'programmi di ricerca scientifici'. Torino: Giappichelli.

De Gobbis, F. (1925). Il bilancio delle società anonime. Milano: Società Editrice Dante Alighieri.

Di Pietra, R., McLeay, S., \& Riccaboni, A. (2001). La regolazione del Bilancio di esercizio: modelli teorici ed esperienza italiana. Rivista dei Dottori Commercialisti, 52, 901-36.

Di Stefano, G. (1991). Per una analisi delle cause esogene della crisi del sistema bestano'. Rivista Italiana di Ragioneria e di Economia Aziendale, 91. 


\section{$\triangle 1$ Macrothink}

International Journal of Accounting and Financial Reporting

ISSN 2162-3082

Donna, G. (1999). La creazione di valore nella gestione dell'impresa. Roma: Carocci.

Faccipieri, S., \& Rullani, E. (1982). Regole di valutazione e indeterminatezza nella scienza economica d'azienda: un problema irrisolto nel pensiero di Gino Zappa. La determinazione del reddito nelle imprese del nostro tempo alla luce del pensiero di Gino Zappa. Atti della giornata di studio nel centenario della nascita di Gino Zappa, Ca' Foscari, 4 aprile 1981, Padova: Cedam.

Franceschi Ferraris, R. (2013). Egidio Giannessi: un precursore dell'internazionalizzazione. Contabilità e Cultura Aziendale, 13, 153-65.

Galassi, G. (1996). Zappa, Gino (1879-1960). In M. Chatfield, \& R. Vangermeersch (Eds.), The history of accounting: an international encyclopedia. New York: Garland Publishing.

Giannessi, E. (1935). I costi di produzione nelle imprese tessili cotoniere. Firenze: Seeber.

Giannessi, E. (1943). Costi e prezzi-tipo nelle aziende industriali. Milano: Giuffrè.

Giannessi, E. (1954). Attuali tendenze delle dottrine economico-tecniche italiane. Pisa: Cursi.

Giannessi, E. (1956). Il piano finanziario nel sistema dei piani d'azienda. Pisa: Libreria Goliardica.

Giannessi, E. (1960). Le aziende di produzione originaria, Vol. I. Le aziende agricole, Pisa: Cursi.

Giannessi, E. (1961). Interpretazione del concetto di azienda pubblica. Milano: Giuffrè.

Giannessi, E. (1969). Considerazioni critiche intorno al concetto di azienda. In Scritti in onore di Giordano dell'Amore. Saggi di discipline aziendali (Vol. 1). Milano: Giuffrè.

Giannessi, E. (1971). Ricordo di Alberto Riparbelli. Pisa: Cursi.

Giannessi, E. (1978). Osservazioni intorno al significato dei bilanci. In Studi in memoria di Federigo Melis (Vol. 5). Napoli: Giannini.

Giannessi, E. (1980). I precursori in Economia Aziendale. Milano: Giuffrè.

Giannessi, E. (1982). Il Kreislauf tra costi e prezzi come elemento determinante delle condizioni di equilibrio del sistema d'azienda. Milano: Giuffrè.

Giannessi, E. (1982). L'equazione del fabbisogno di finanziamento nelle aziende di produzione e le possibili vie della sua soluzione. Milano: Giuffrè.

Giannessi, E. (1992). Considerazioni introduttive sul metodo storico. Milano: Giuffrè.

Gonnella, E. (2012). Financial Statement Valuations in Italian Accounting Thought Between the 19th and the 20th Century: From "Exchange Value" to "Historical Cost". Journal of Modern Accounting and Auditing, 8, 1255-1271.

Gonnella, E. (2014). L'azienda di produzione. Elementi costitutivi, condizioni operative, creazione di valore. Milano: FrancoAngeli. 


\section{$\triangle$ Macrothink}

International Journal of Accounting and Financial Reporting

ISSN 2162-3082

Gonnella, E. (2017). The 'Functional Value' (Valore Funzionale) in the Tuscan School of 'Economia Aziendale': the Contribution of Alberto Ceccherelli and Egidio Giannessi to Financial Valuation Theory. In D. Alexander et al. (Eds.), The History and Tradition of Accounting in Italy. London: Routledge.

Gonnella, E., \& Talarico, L. (2012). Italian Accounting of the Late 19th Century and the Early 20th Century on the Epistemological Problem of Connections With Related Sciences. Journal of Modern Accounting and Auditing, 8, 1095-1125.

Guatri, L., \& Vicari, S. (1994). Sistemi d'impresa e capitalismi a confronto: creazione di valore in diversi contesti. Milano: EGEA.

Iannone, G. (1993). La valutazione funzionale: applicabilità nel contesto civilistico attuale. In Rivista Italiana di Ragioneria e di Economia Aziendale (p. 93).

Lee, T. A. (1998). Income and Value Measurement. Theory and Practice. London: Chapman \& Hall.

Lee, T. A. (2009). Financial Accounting Theory. In J. R. Edwards, \& S. P.Walker (Eds.), The Routledge Companion to Accounting History. London: Routledge.

Marasca, S. (1999). Le valutazioni nel bilancio d'esercizio. Torino: Giappichelli.

Mattessich, R. (2008). Two Hundred Years of Accounting Research. London and New York: Routledge.

Miolo Vitali, P., \& Gonnella, E. (2006). Egidio Giannessi: la figura del Maestro e il suo fondo bibliotecario. Rivista Italiana di Ragioneria e di Economia Aziendale, 106, 576-589.

Musaio, A. (2005). La riforma del diritto societario. Profili Economico-Aziendali. Milano: FrancoAngeli.

Negru, I. (2013). Revisiting the Concept of Schools of Thought in Economics: The Example of the Austrian School. American Journal of Economics and Sociology, 72, 983-1008.

Onida, P. (1940). Il bilancio d'esercizio nelle imprese. Significato economico del bilancio: problemi di valutazione. Milano: Giuffrè.

Pantaleoni, M. (1904). Alcune osservazioni sulle attribuzioni di valori in assenza di formazione di prezzi di mercato. Giornale degli Economisti, 28, 203-231.

Paolini, A. (2013). L'oggetto della rilevazione periodica: il reddito di esercizio ed il capitale di funzionamento. In L. Marchi (Ed.), Introduzione alla contabilità d'impresa. Torino: Giappichelli.

Poli, R. (1971). Il bilancio d'esercizio: evoluzioni e prospettive nell'economia dei paesi industrialmente progrediti. Milano: Giuffrè.

Ponzanelli, G. (1956). Breve introduzione allo studio dell'economia aziendale: delineazione dei problemi dell'azienda contemporanea. Firenze. 


\section{I Macrothink}

International Journal of Accounting and Financial Reporting

ISSN 2162-3082

2018, Vol. 8, No. 4

Ponzanelli, G. (1961). Lineamenti di economia generale delle aziende. Firenze: Davite.

Ponzanelli, G. (1964). La determinazione e la rilevazione dei costi di produzione nelle imprese industriali. Siena: Industria Grafica Pistolesi.

Riparbelli, A. (1943). Aspetti tecnico-contabili delle disposizioni del nuovo codice civile in materia di bilanci di società per azioni. Firenze: Coppini.

Riparbelli, A. (1950). Il contributo della ragioneria nell'analisi dei dissesti aziendali. Firenze: Vallecchi.

Riparbelli, A. (1952). Il primato italiano nelle applicazioni della ragioneria e negli studi economico aziendali, Prolusione tenuta nell'Università degli Studi di Catania il 29 gennaio 1952. In Studi di Economia e Statistica (Serie 1, vol. II). Catania: Facoltà di Economia e Commercio.

Riparbelli, A. (1954). Correlazioni ed interdipendenze fra gli organismi aziendali e $i$ loro rapporti con le rilevazioni interne. Firenze: Linari.

Riparbelli, A. (1962). Correlazioni ed interdipendenze fra organismi aziendali. Pisa: Cursi.

Riparbelli, A. (1968). Ricordando Alberto Ceccherelli nel decennio della sua scomparsa. In A. Riparbelli (Ed.), Atti del seminario sulle opere del Prof. Alberto Ceccherelli tenuto nell'anno accademico 1967-68. Firenze: Coppini.

Schumpeter, J. A. (2006). History of Economic Analysis. London: Routledge.

Tozzi, I. et al. (2012). L'impatto dell'adozione degli IAS/IFRS sui bilanci delle aziende di servizi. In L. Marchi, \& L. Potito (Eds.), L'impatto dell'adozione degli IAS/IFRS sui bilanci delle imprese italiane quotate. Milano: FrancoAngeli.

Viganò, E. (1998). Accounting and Business Economics Traditions in Italy. European Accounting Review, 7, 381-403.

Vigano, E., \& Mattessich, R. (2007). Accounting research in Italy: second half of the 20th century. Review of Accounting and Finance, 6, 24-41.

VV.AA. (1994). Atti della giornata di studi giannessiani. Pisa, 30 ottobre 1992, Milano, Giuffrè.

Whittington, G. (2010). Measurements in financial reporting. Abacus, 46, 104-110.

Zambon, S. (1996). Accounting and Business Economics Traditions: a Missing European Connection?. European Accounting Review, 5, 401-11.

Zambon, S., \& Zan, L. (2000). Accounting relativism: the unstable relationship between income measurement and theories of the firm. Accounting, Organizations and Society, 25, 799-822.

Zan, L. (1994). Toward a History of Accounting Histories. European Accounting Review, 3, 255-307. 
Zappa, G. (1910). Le valutazioni di bilancio con particolare riguardo ai bilanci delle società per azioni. Milano: Società Editrice Libraria.

Zappa, G. (1920-1929). La determinazione del reddito nelle imprese commerciali. I valori di conto in relazione alla formazione dei bilanci. Roma: Anonima Libraria Italiana.

\section{Notes}

Note 1. In the Thirties, after the sudden stop caused by the 1929 crisis, two important events took place: 1) the Istituto per la Ricostruzione Industriale (IRI) was created in 1933 and, consequently, the entire capital of mixed banks and their equity interests held in the main Italian industrial firms was nationalized (IRI would purchase over $20 \%$ of the national share capital and become the larger Italian entrepreneur); 2) a Legge Bancaria (Banking Law) was promulgated in 1936 to establish a clear separation between deposit banking and investment banking, putting an end to the mixed banks that had been crucial until then for the industrial development of the country and, although only to a limited extent, of stock exchanges. The Italian State then intervened in the economy with more institutions, such as Fondo Industria Meccanica (1947), subsequently transformed in to Ente Partecipazioni e Finanziamento Industrie Manifatturiere (EFIM, 1962), Cassa del Mezzogiorno (1950) and Ente Nazionale Idrocarburi (ENI, 1953).

Note 2. As regards the different procedures for the issuing of accounting regulations, an abstract distinction is usually made between the 'bureaucratic model', the 'delegate model' and the 'self-regulation model' (Di Pietra, McLeay and Riccaboni 2001: pp. 920-923).

Note 3. 'Italian law protected the interests of creditors by imposing a very conservative regime on inventory valuation, rather than requesting a "true and fair view" of economic and financial position of firms' (Bergamin Barbato et al. 1996: p. 149).

Note 4. It was the Commissione per la Statuizione dei Principi Contabili (CSPC, Commission for the definition of accounting principles), which started working in 1975. It is worthwhile remembering that, initially, the documents produced by the Commission and the related accounting principles had no prescriptive value. It was only in 1989 that the Commissione Nazionale per le Società e la Borsa (CONSOB, the National Commission for Companies and the Stock Exchange), with its own resolution, recommended that listed companies should implement Corretti Principi Contabili (Correct Accounting Principles), thus recognising for the first time the standards issued by CSPC (see: Di Pietra, McLeay and Riccaboni, 2001: p. $68 \mathrm{ff}$.$) .$

Note 5. Furthermore, Zappa observed: 'Within a coordinated whole... elements have a value which they lose when they are torn away from it. The patterns of aggregation of elements, their integration, their succession, converge... in shaping the characteristics of the whole. For reasons of scientific abstraction or of concrete approximate perception, the analysis can separate the unitary phenomenon in its elements, but it should not remain unaware of the "reality". And the relations which connect the part to the whole to which it pertains are not 
something which is fortuitous or extrinsic to "reality" (Zappa 1920-29: p. 331).

Note 6. Referring to Zappa's thought, Mattessich said: 'The "balance sheet capital" was determined through the interdependence of the values of its individual elements. In other words, the value of one item was seen as dependent on all the others and vice versa. This stems from the interdependence of the production factors represented by those values' (2008: pp. 88-89).

Note 7. The three students, according to Bertini, in giving '.. their own personal contribution to the development of the Tuscan School', showed that they were '... all perfectly aligned with the positions of Alberto Ceccherelli' (2010: p. 681).

Note 8. Actually, the theory of the azienda will find its centre of gravity in the theory of the firm (for-profit azienda). Referring to the content of Economia Aziendale, Ceccherelli observed: 'The general scope of this discipline is the azienda, but the phenomena that feed its scientific investigation essentially belong to the firm' (1948: p. 63). As to the development of Economia Aziendale, particularly referring to the phenomenon of the firm, see, inter alia: Capaldo 2010: pp. 19-22; 2013, pp. 492-498).

Note 9. The idea has been adopted by Ceccherelli's disciples, including Giannessi: 'In scientific investigation, ... after observing facts one must proceed with the burdensome processing of theories ...' (1980: p. 73).

Note 10. '... no reporting is feasible by directly applying schemes and conventional formulae' (Ceccherelli 1934: p. 122).

Note 11. According to Giannessi, it is exactly with Ceccherelli that '... studies on the meaning of numbers, figures, and accounting statements have been initiated' (Giannessi 1954, p. 417).

Note 12. For more insights on the development of Italian Ragioneria in close connection with Economia Aziendale, see, inter alia, Zan (1994), Viganò (1998), Zambon (1996), Zan and Zambon (2000).

Note 13. That same year he obtained a teaching qualification in Accounting and Calculations (Corticelli 1982: p. 488).

Note 14. For more exhaustive references, see Gonnella, 2017, p. 95.

Note 15. The formulation of a general theory of the azienda brings Giannessi to replace the figure of the entrepreneur, traceable in the profit organizations only, with the broader figure of 'soggetto economico' - translated by the authors with 'economic actor' - that embraces the not-for-profit and public organizations too.

Note 16. '... a factor provided with a degree " $x$ " of usefulness may not find its full utilization within the azienda if the other factors do not own " $y$ ", " $z$ ", etc. usefulness capable of combining with it in the most convenient manner...' (Giannessi 1969: p. 513).

Note 17. 'An azienda combination is not such if the factors that perform a function in 
production are not proportional with each other' (Giannessi 1969: p. 513).

Note 18 . The term aziende is the plural of the term azienda.

Note 19. On the theme of 'firm-specific valuations', see Whittington, 2010, pp. 106-107 and Barth, 2010, pp. 123-124.

Note 20. ' $\ldots$ the problem of valuations - as Giannessi maintains - cannot be resolved with the choice of any criterion from those existing, the application of a "simple rule" dictated by a law or found in any of the many accounting manuals ...' (Giannessi 1981: p. 66).

Note 21. 'Valuation is not an exclusively quantitative problem... Figures substantiate the judgement that expresses the quantitative-qualitative position of an asset at a given time compared to the environmental complex that makes up its orbit' (Giannessi 1960: p. 589).

Note 22. The functional values stemming from such a valuation process may be lower or higher than the purchase cost of the asset. As Giannessi clarified, the former case is the norm, the second the exception (Giannessi 1960: pp. 686-689). From a book-keeping perspective, in the first case, you will have to depreciate, while in the second, when you have increases in functional value due to the improvement of the degree of functionality of assets, such increases '... must always be neutralised by contra asset accounts of the same amount ...' (Giannessi 1960: p. 764).

Note 23. 'Valuation is not an exclusively quantitative problem ... Figures are the concrete expression of the judgement that reflects the quantitative/qualitative position of an asset at a given moment in time with respect to the whole environment that is its orbit' (Giannessi 1960: p. 589).

Note 24. 'In English-speaking countries the archetypical enterprise is medium or large, with many shareholders (if it is a public company). There, the fundamental problem relates to the choice of the manager and the assessment of his or her success. In Continental Europe, however, the azienda is, or used to be, typically medium or small in size-often being a sole or one-family proprietorship. Widespread shareholding was much rarer, and capital markets did not function as effectively. The owner was the only possible manager, self-elected, self-imposed, self-approved, practically irremovable. The problem of selection and evaluation of his activity rarely arose.' (Vigano and Mattessich 2007: p. 25).

Note 25. 'However, we cannot exclude that income and financial position data obtained by applying functional values may also be useful for minority shareholders and for creditors, if it is true that - unlike, for example, with values expressed by the market - they are derived from facts and information sometimes confidential and only available to the management' (Gonnella, 2017: p. 116).

Note 26. Connecting the value attributed to an asset in the financial statement not only with its intrinsic characteristics, but also to its degree of functionality within the azienda has become a consolidated notion and practice in accounting regulation, although it has not yet found a specific coding either in international accounting standards (IAS/IFRS) or in Italian accounting principles (OIC). A recurring example of the case where the change of usage of 


\section{1l Macrothink}

International Journal of Accounting and Financial Reporting

ISSN 2162-3082

2018, Vol. 8, No. 4

an asset requires the re-determination of its value is that of a fixed asset to be sold, where there is a passage from its value-in-use to its liquidation value. Another example of the link between the value of an asset and its economic function is the impairment test (IAS 36), which requires a definition of the recoverable amount, i.e. the higher between the value-in-use and the fair value less costs to sell. The value-in-use is formulated precisely on the basis of the expectations of the specific azienda with reference to the economic contribution that the asset is able to provide to the operations.

Note 27. We can find different kinds of references to the complementarity of the assets and to the consequent implications on the financial valuations in others Italian scholars as inter alia: Besta 1909: II, p. 14; Pantaleoni 1904: pp. 219-221; Zappa 1910: pp. 112-113; Alfieri 1923: p. 268; De Gobbis 1925: pp. 122-123. See also: Gonnella 2012.

Note 28. 'The individual estimates ..., although referred to certain elements, reflect, together with particular aspects, relational aspects ...' (Corticelli 1981: p. 95).

Note 29. On the presence of future expectations in financial statements, see Barth 2006.

Note 30. In truth, the same problem can also be observed in Anglo-Saxon studies. In this regard, Lee noted: ' $\ldots$ the financial accounting theory contributions of writers such as Hatfield, Paton, Chambers, and Sterling can be argued to have had marginal impact on the general state of practice and education ...' (Lee 2009: p. 157).

Note 31. Schumpeter, a well-known economist with a great historical-doctrinal culture, conceived the theory of value as a 'causal explanation of the phenomenon of value' (Schumpeter 2006: p. 309; see also Gonnella and Talarico 2012: pp. 1115-1121).

Note 32. For an accurate overview of the various valuation theories proposed by Anglo-Saxon scholars, see among others: Lee 1998 and 2009.

\section{Copyright Disclaimer}

Copyright for this article is retained by the author(s), with first publication rights granted to the journal.

This is an open-access article distributed under the terms and conditions of the Creative Commons Attribution license (http://creativecommons.org/licenses/by/4.0/) 